\title{
Antihyperlipidemic And Glucose Lowering Effect Of Extract Of Bioregulator Treated Okra (Abelmoschus Esculentus L.) Fruits in Triton-Induced Hyperlipidemia Rats
}

\author{
A.M. Esan, ${ }^{1}{ }^{*}$ C.O. Olaiya ${ }^{1}$, V. Sameer, ${ }^{2}$ K. Elango ${ }^{2}$, S.P. Dhanabal ${ }^{2}$ \\ ${ }^{I}$ Department of Biochemistry, Faculty of Basic Medical Sciences, University of Ibadan, Oyo state, Nigeria \\ ${ }^{2}$ JSS College of pharmacy, Tamil Nadu, Ooty, India \\ Corresponding Author: A.M. Esan
}

\begin{abstract}
Extracts from okra have been used to alleviate not only hyperglycemia but also hyperlipidemia in diabetic mice induced by alloxan and streptozocin. However, its hypolipidemic activity has not yet been clearly studied. This study was aimed to study the antihyperlipidemic potential of bioregulator treated okra fruit in triton-X induced hyperlipidemic rats. Hyperlipidemia was induced in rats by administration of triton-X $(100 \mathrm{mg} / \mathrm{kg}$ i.p.). After 14 days of induction, hyperlipidemic rats received AWB (okra extract treated with bioregulator, AWOB (okra extract without bioregulator) and atorvastatin up to 28 days. The extracts activities were assessed on serum blood glucose, lipid profiles, carbohydrate enzymes, antioxidant and non-enzymes antioxidant enzymes, malondialdehyde level, and $H M G$-CoA reductase activity of control and drug-treated rats. The extract exhibited a strong dose-dependent antihyperlipidemic activity and at dose level $400 \mathrm{mg} / \mathrm{kg}$ (AWB) p.o. the extract showed a significant $(P \leq 0.05)$ decrease in blood glucose, TC, TG, LDL, VLDL, MDA, gluconeogenic enzymes and significant $(P \leq 0.05)$ increase in $H D L-C$, glycogenic enzymes, antioxidant enzymes and non-enzymes antioxidant in a dose- dependent manner comparing with standard atorvastatin- treated group. The present study demonstrated that the extract of bioregulator treated okra exhibits a potent lipid lowering activity and well compared with the atorvastatin than extract without bioregulator.
\end{abstract}

Keywords: Bioregulator, Carbohydrate enzymes, lipid profiles, Okra, Triton-X.

Date of Submission: 23-05-2017

Date of acceptance: $17-07-2017$

\section{Introduction}

Hyperlipidemia is a complicated disorder with a hallmark of elevated serum total cholesterol, lowdensity and very low-density lipoprotein cholesterol, triglycerides, and decreased high-density lipoprotein levels [1]. Hyperlipidemia has been implicated in atherosclerosis, which is the primary cause of heart disease and stroke [2]. About two-third of the cholesterol made in the body is synthesized by the liver. Lipid metabolism is controlled majorly in different ways. Enzymes play a pivot role in lipid metabolism; in cholesterol synthesis, the rate limiting enzyme is 3-hydroxy-3-methylglutaryl (HMG)-CoA reductase that regulates cholesterol concentrations in the cells by feedback inhibition. Insulin resistance and obesity are closely linked with the infiltration of adipose tissue by inflammation cells [3]. Insulin resistance, a common accompaniment of obesity, is a major risk factor for diabetes mellitus [4]. Increased extracellular and intracellular glucose concentrations resulted in oxidative stress is due to increased production of ROS and a sharp decrease in antioxidant body defenses [5]. The onset of diabetes complications, oxidative stress plays a key role notably diabetic nephropathy [6]. Treatment of hyperlipidemia involves diet control, exercise, and the use of lipid-lowering diets and drugs [7]. For the treatment of hyperlipidemia, the most common drugs used include 3-hydroxy-3-methylglutaryl (HMG)-CoA reductase inhibitors, also known as statins. Bile acid sequestrants (anion-exchange resins) such as cholestyramine and colestipol; fibrates such as clofibrate, gemfibrozil, fenofibrate, ciprofibrate, and bezafibrate; niacin; cholesterol absorption inhibitors such as ezetimibe; and omega-3-fatty acids are others drugs employed for the treatment of hyperlipidemia [8]. Many hypolipidemic drugs have already been proved to be useful in lowering serum lipid levels in patients. However, its side effects in long-term treatment have been frequently reported and its therapy is still deprived of the efficiency, safety, For example, severe muscle damage is reported with statins, which are particularly well suited for lowering Low- density lipoprotein [9]. Niacin, a drug for reducing triglycerides levels may cause hyperlipidemia and which in turn can lead to liver damage [10]. Adverse reactions of Achilles tendon xanthomas have been reported after the addition of niacin and bile acid sequestrants to ongoing statin therapy in patients with hypercholesterolemia [11]. Prices are still expensive. Thus, efforts to develop effective and better hypolipidemic drugs had led to the discovery of natural agents. 
Abelmoschus esculentus is used for ages as an edible vegetable in many countries and commonly eaten in Vietnam because of its nourishing components. Traditionally, it is believed that the plant is useful in the treatment of inflammatory disorders, constipation, retention of urine, and etc. On the other hand, a number of previous studies have reported that Abelmoschus sp. possessed hypoglycemic effect. However, there is a little study regarding its hypolipidemic effect. The aim of this present study is to investigate and evaluate the hypolipidemic effect of bioregulator treated A. esculentus extracts on triton-induced hyperlipidemia in rats to provide scientific evidence for the development of $A$. esculentus as a potential natural oral hypolipidemic agent or functional food.

\subsection{Plant material}

\section{Materials And Methods}

\subsection{Preparation of plant extract}

$450 \mathrm{~kg}$ of dried fruit powdered of both treated (AWB) and untreated (AWOB) okra samples of the same genotype were used for this experiment; fruit powdered of Abelmoschus esculentus L. seeds treated with 0.4 $\mathrm{mM}$ of indole acetic acid and fruit powdered of Abelmoschus esculentus L. seeds without any treatment were extracted with $70 \%$ hydro-alcohol by maceration in a round bottom flask for $72 \mathrm{hrs}$. The solvent was filtered, and the combined filtrate was concentrated in-vacuo using a water bath and kept in a desiccator to obtain paste extract (Abelmoschus esculentus).

\subsection{Chemicals and Reagents}

Triton-X- $100(100 \mathrm{mg} / \mathrm{kg}), \mathrm{CMC}$ and atorvastatin $30 \mathrm{mg} / \mathrm{L}$ were purchased from Sigma-Aldrich. All other biochemicals used in this experiment were purchased from Sigma-Aldrich, USA. All the chemicals were of analytical grade.

\subsection{Experimental animals}

Sprague Dawley male rats, weighing 150-200g were obtained from the institutional animal house for the present investigations. The animals were housed at a room temperature of $25 \pm 20 \mathrm{C}$, relative humidity of $75 \pm 5 \%$ and $12 \mathrm{hrs}$ dark-light cycle, animals were provided basal standard rat diet and water ad libitum. The animals were acclimatized to laboratory condition for five days before commencement of the experiment. The experiments were conducted according to the ethical norms and Institutional Animal Ethics Committee Guidelines.

\subsection{Experimental design}

The rats were divided into seven groups comprising of five animals each ( $n=5)$ (35 animals). The standard drug atorvastatin and extracts were suspended in $0.2 \% \mathrm{w} / \mathrm{v}$ carboxymethyl cellulose (CMC) for oral administration.

Group I: Normal control fed with standard diet, and rats received $0.2 \%$ CMC (10 ml) orally 2 h before feeding the animals with a normal diet.

Group II: served as obese control received a single dose of triton administered at a dose of 100mg/kg, i.p. After 72 hours of triton injection, this group received a daily dose of $0.2 \% \mathrm{CMC}$ (p.o) for 7 days.

Group I11: served as Abelmoschus esculentus without bioregulator (AWOB) were administered with a daily dose of extract 200mg/kg (Sabitha et al., 2011) dissolved in 0.2\% CMC (p.o) treated obese rats, for 14 days after induction of hyperlipidemia.

Group 1V: served as Abelmoschus esculentus without bioregulator (AWOB) were administered with a daily dose of extract $400 \mathrm{mg} / \mathrm{kg}$ dissolved in $0.2 \%$ CMC (p.o) treated obese rats, for 14 days after induction of hyperlipidemia.

Group V: served as Abelmoschus esculentus with bioregulator (AWB) were administered with a daily dose of extract $200 \mathrm{mg} / \mathrm{kg}$ dissolved in $0.2 \%$ CMC (p.o) treated obese rats, for 14 days after induction of hyperlipidemia.

Group VI: served as Abelmoschus esculentus with bioregulator (AWB) were administered with a daily dose of extract $400 \mathrm{mg} / \mathrm{kg}$ dissolved in $0.2 \%$ CMC (p.o) treated obese rats, for 14 days after induction of hyperlipidemia. Group V11: served as a standard drug, were administered with a daily dose of atorvastatin $30 \mathrm{mg} / \mathrm{kg}$ dissolved in $0.2 \% \mathrm{CMC}$ (p.o) treated obese rats for 14 days after induction of hyperlipidemia.

Blood samples were taken from a tail vein on $0,7^{\text {th }}, 14^{\text {th }}, 21^{\text {st }}$ and $28^{\text {th }}$ day for blood glucose level determination using one touch glucometer purchased from Lifescan Europe Division of Cilag GmbH International $6300 \mathrm{Zug}$ Switzerland.

\subsection{Collection of blood for serum glucose and lipid profiles}

Blood samples after 24 hours of the last dose were collected from retro-orbital plexus and allowed to coagulate at room temperature which was then centrifuged at $3000 \mathrm{rpm}$ for 10 minutes. The serum was 
separated and used for the biochemical estimations of TC, TG and HDL-C using commercially available kits [12]. The fractions of LDL-C and VLDL-C in the serum were calculated by using Friedewald's equation [13] as follows:

LDL-C $=$ Total cholesterol $-($ HDL-C + VLDL-C)

VLDL-C = Triglyceride $/ 5$

Finally, at the $28^{\text {th }}$ day, all rats were sacrificed, liver isolated and washed with $1.15 \% \mathrm{KCl}$, dried and weighed for biochemical estimations.

\subsection{Measurement of Body Weight, Relative Liver, and Heart}

Body weights of animals of all groups were measured every week for consecutive four weeks. But relative liver and heart weight of the animals were measured on the 28th day after sacrificing the animals. Relative liver and heart weight were calculated by applying the following formula [14]:

Relative weight $=\frac{\text { Organ weight }}{\text { Body weight }} \times 100$

I

\subsection{Biochemical Estimations in Liver Homogenate \\ 2.8.1 Estimation of carbohydrate metabolizing enzymes activities \\ 2.8.1.1 Assay for hexokinase activity}

Hexokinase -D was assayed by the method of [15] with some modifications. Briefly, the reaction was initiated by the addition of $1.3 \mathrm{~mL}$ of tissue homogenate. $1.0 \mathrm{~mL}$ aliquot of the reaction mixture was taken immediately (zero time) to tubes containing $1.0 \mathrm{~mL}$ of $10 \%$ TCA. A second aliquot was removed after $30 \mathrm{~min}$ of incubation at $37^{\circ} \mathrm{C}$ and added to tubes containing $1.0 \mathrm{~mL}$ of $10 \%$ TCA. The precipitated protein was removed by centrifugation and the residual glucose in the supernatant was estimated. A reagent blank was run with each test. The difference between the two values gave the amount of glucose phosphorylated. The enzyme activity was expressed as $\mu / \mathrm{mol}$ of glucose phosphorylated $/ \mathrm{h} 1 \mathrm{mg}$ protein.

\subsubsection{Assay for glucose - 6 - phosphate dehydrogenase activity}

Glucose- 6-phosphate dehydrogenase in the erythrocytes and liver was assayed by the method of [16] with some modifications. Briefly, the incubation in a total volume of $5.5 \mathrm{~mL}$ contained $1.0 \mathrm{~mL}$ of tris buffer, 0.1 $\mathrm{mL}$ of magnesium chloride, $0.1 \mathrm{~mL}$ of NADP+, $0.5 \mathrm{~mL}$ of phenazine methosulphate, $0.4 \mathrm{~mL}$ of the dye solution and the requisite amount of the enzyme extract. The mixture was allowed to stand at room temperature for 10 min to permit the oxidation of endogenous materials. The reaction was initiated by the addition of $0.5 \mathrm{~mL}$ of glucose 6-phosphate. The absorbance was read at $640 \mathrm{~nm}$ against water blank: at one- minute intervals for 3.5 min in a UV spectrophotometer. The activity of the enzyme was calculated in units by multiplying the change in $\mathrm{OD} / \mathrm{min}$ by the factor $6 / 17.6$, which is the molar extinction coefficient of the reduced enzyme activity.

\subsubsection{Assay for glucose-6-phosphatase activity}

Glucose 6-phosphatase was assayed by the method of [17] with slight modifications. Briefly, the incubation mixture contained $0.3 \mathrm{~mL}$ buffer, $0.5 \mathrm{~mL}$ glucose 6-phosphate and $0.2 \mathrm{~mL}$ tissue homogenate. This was incubated at $37^{\circ} \mathrm{C}$ for $1 \mathrm{hr} .1 \mathrm{~mL} 10 \%$ TCA was added to the tubes to terminate the enzyme activity, then centrifuged and the phosphate content of the supernatant was estimated by [18] method. To $1 \mathrm{~mL}$ of the aliquot of the supernatant, $1 \mathrm{~mL}$ of ammonium molybdate and $0.4 \mathrm{~mL}$ ANSA were added. The blue color developed was read after $20 \mathrm{~min}$ at $620 \mathrm{~nm}$. A tube devoid of the enzyme served as control. A series of standards containing 8-40 $\mu \mathrm{g}$ of phosphorus was treated similarly along with a blank containing only the reagent. The enzyme activity was expressed as $\mu \mathrm{mol}$ of inorganic phosphorus liberated $/ \mathrm{min} / \mathrm{mg}$ of protein.

\subsubsection{Assay for fructose 1, 6-bisphosphatase activity}

Fructose 1, 6-bisphosphatase was assayed by the method of [19] with some modifications. Briefly, The assay medium in a final volume of $2.0 \mathrm{~mL}$ contained $1.0 \mathrm{~mL}$ buffer, $0.4 \mathrm{~mL}$ of the substrate, $0.1 \mathrm{~mL}$ each of magnesium chloride, $0.2 \mathrm{~mL}$ potassium chloride, $0.1 \mathrm{~mL}$ of EDTA and $0.2 \mathrm{~mL}$ of enzyme source. The incubation was carried out at $37 \mathrm{C}$ for $15 \mathrm{~min}$. The reaction was terminated by the addition of $1.0 \mathrm{~mL}$ of $10 \%$ TCA. The suspension was centrifuged and the phosphorus content of the supernatant was estimated according to the method described by [18]. To $1 \mathrm{~mL}$ of an aliquot of the supernatant, $0.3 \mathrm{~mL}$ of distilled water and $0.5 \mathrm{~mL}$ of ammonium molybdate were added. After $10 \mathrm{~min}, 0.2 \mathrm{~mL}$ of ANSA was added. The tubes were shaken well, kept aside for $20 \mathrm{~min}$ and the blue color developed was read at $620 \mathrm{~nm}$. The values were expressed as $\mu / \mathrm{mol}$ of inorganic phosphorus liberated/h1 mg protein. 


\subsubsection{Estimation of Malondialdehyde Levels}

Malondialdehyde (MDA), an index of free radical generation/lipid peroxidation, was measured in liver homogenate by using the procedure as reported earlier [20] with slight modification. Briefly, the tissue sample (100 mg of the liver) was homogenized in $9.0 \mathrm{~mL}$ of $1.15 \% \mathrm{KCL}$. Briefly, the reaction mixture consisted of $0.2 \mathrm{~mL}$ of $8.1 \%$ sodium lauryl sulphate, $1.5 \mathrm{~mL}$ of $20 \%$ acetic acid $(\mathrm{pH} 3.5)$, and $1.5 \mathrm{~mL}$ of $0.8 \%$ aqueous solution of thiobarbituric acid added to $0.2 \mathrm{~mL}$ of liver homogenate. The mixture was made up to $4.0 \mathrm{~mL}$ with distilled water and heated at $95^{\circ} \mathrm{C}$ for $60 \mathrm{~min}$. After cooling the contents under running tap water, $5.0 \mathrm{~mL}$ of $\mathrm{n}$-butanol and pyridine $(15: 1 \mathrm{v} / \mathrm{v})$ and $1.0 \mathrm{~mL}$ of distilled water were added. The contents were centrifuged at about $4000 \mathrm{rpm}$ for $10 \mathrm{~min}$. The organic layer was separated out and its absorbance was measured at $532 \mathrm{~nm}$ using double beam UV-Visible spectrophotometer against a reagent blank. MDA values were calculated using the extinction coefficient of MDA-thiobarbituric acid complex $1.56 \times 1051 / \mathrm{mol} \times \mathrm{cm}$ and expressed as $\mathrm{nmol} / \mathrm{mg}$ tissue.

\subsubsection{Estimation of HMG-CoA Reductase Activity (HMGCoA/Mevalonate Ratio)}

HMG-CoA reductase activity was measured in liver homogenate using the procedure of [21] with slight modification. Briefly, the ratio of HMG-CoA to mevalonate was taken as an index of enzyme activity which catalyzes the conversion of HMG to mevalonate, the lower the ratio the higher the enzyme activity. The liver sample $(100 \mathrm{mg})$ was homogenized in $1.0 \mathrm{~mL}$ of arsenate $(1 \mathrm{gm} / \mathrm{L})$ solution. Equal volumes $(0.5 \mathrm{~mL}$ each $)$ of fresh liver $10 \%$ tissue homogenate and diluted perchloric acid $(50 \mathrm{~mL} / \mathrm{L})$ were mixed together. This was allowed to stand for 5 minutes and centrifuged at about 2000rpm for $10 \mathrm{~min}$. This was filtered and $1 \mathrm{~mL}$ of the filtrate was mixed with $0.5 \mathrm{~mL}$ of freshly prepared hydroxyl amine $(2 \mathrm{~mol} / \mathrm{L})$ reagent of $\mathrm{pH} 5.5 \mathrm{for} \mathrm{HMG}-\mathrm{CoA}$ and with $0.5 \mathrm{~mL}$ of freshly prepared hydroxyl amine $(2 \mathrm{~mol} / \mathrm{L})$ reagent of $\mathrm{pH} 2.1$ for mevalonate. After 5 minutes, $1.5 \mathrm{~mL}$ of ferric chloride reagent (prepared by dissolving $5.2 \mathrm{gm}$ of trichloroacetic acid and $10 \mathrm{gm}$ of ferric chloride in $50 \mathrm{~mL} 0.65 \mathrm{~mol} / \mathrm{L} \mathrm{HCl}$ ) was added to each of the test tubes for HMG-CoA and mevalonate. The tubes were shaken well. Absorbance was read after $10 \mathrm{~min}$ at $540 \mathrm{~nm}$ versus a similarly treated arsenate blank using a double beam UV-Visible spectrophotometer.

\subsubsection{Estimation of antioxidants activities levels}

2.8.4.1 Assay for catalase activity

Catalase activity was determined by the method of [22] with some modification. Briefly, the reaction solution of CAT activities contained $2.5 \mathrm{ml}$ of $50 \mathrm{mM}$ phosphate buffer ( $\mathrm{pH} \mathrm{5.0),} 0.4 \mathrm{ml}$ of $5.9 \mathrm{mM} \mathrm{H}_{2} \mathrm{O}_{2}$ and $0.1 \mathrm{ml}$ enzyme extract. Changes in absorbance of the reaction solution at $240 \mathrm{~nm}$ were determined after one minute. One unit of CAT activity was defined as an absorbance change of 0.01 as units $/ \mathrm{min}$.

\subsubsection{Assay for superoxide dismutase activity}

Superoxide dismutase was assayed for by the method of [23] with slight modifications. Briefly, the assay is based on the inhibition of the formation of NADH phenazine methosulphate, nitroblue tetrazolium formazon. The reaction was initiated by the addition of NADH. After incubation for $90 \mathrm{sec}$, the reaction was stopped by adding glacial acetic acid. The color developed at the end of the reaction was extracted into the nbutanol layer and measured in a Spectronic 20 at $520 \mathrm{~nm}$.

\subsubsection{Assay for glutathione peroxidase activity}

The activity of GPx was measured by the method of [24] with some modifications. Briefly, a known amount of enzyme preparation was allowed to react with $\mathrm{H}_{2} \mathrm{O}_{2}$ in the presence of GSH for a specified time period. Then the remaining GSH content was measured.

\subsubsection{Estimation of non -enzymatic antioxidants levels}

2.8.5.1 Assay for ascorbic acid (vitamin C)

Ascorbic acid was estimated by the method of [25] with some modifications. Briefly, the ascorbic acid was converted to dehydroascorbic acid by mixing with norit and then was coupled with 2,4 dinitrophenylhydrazines (DNPH) in the presence of thiourea, a mild reducing agent. The coupled dinitrophenylhydrazine was converted into a red colored compound when treated with sulphuric acid and read in a Spectronic 20 at $540 \mathrm{~nm}$.

\subsubsection{Assay for $\alpha$--tocopherol (vitamin E)}

$\alpha$-Tocopherol was estimated by the method of [26] with slight modifications. Briefly, the method involves the reduction of ferric ions to ferrous ions by $\alpha$--tocopherol and the formation of a red colored complex with $2,2^{\prime}$ dipyridyl. The absorbance of the chromophore was measured at $520 \mathrm{~nm}$. 


\section{Statistical Analysis}

All values were expressed as mean \pm SEM. The data were statistically analyzed using one-way (ANOVA) followed by LSD test to detect differences between the groups. The differences were considered to be statistically significant at $P<0.05$.

\subsection{Effect of okra extracts on serum glucose level}

\section{Results}

As shown in figure 1, on the fourth week of the experiment, serum glucose levels of disease control and $\mathrm{DC}+200 \mathrm{mg} / \mathrm{kg}(\mathrm{AWOB})$ groups were significantly $(\mathrm{P} \leq 0.05)$ increased as compared to control levels. But in other treated experimental groups there was no significant increased in serum glucose levels on the fourth week of the experiment as compared to the control group. The administration of the extract was observed to be dosedependent in the reduction of serum glucose levels.

\subsection{Effect of okra extracts on serum lipid profiles}

Triton-induced significant increased in total cholesterol, LDL, VLDL, and atherogenic index (AI). Rats in the disease control group and those treated with DC+ $200 \mathrm{mg} / \mathrm{kg}$ (AWOB) showed significantly increased in the levels of TC, LDL, VLDL and AI in comparison with normal control group. However, serum HDL level of rats in disease control group was reduced when compared with other groups as well as a control group. Treated Abelmoschus esculentus extracts $(400 \mathrm{mg} / \mathrm{kg} \mathrm{p.o})$ and atorvastatin $(30 \mathrm{mg} / \mathrm{kg})$ decreased serum total cholesterol, triglycerides, VLDL, LDL, and atherogenic index with increased HDL levels when compared with disease control group, although the reduction did not return to baseline of normal control group. Higher doses $(400 \mathrm{mg} / \mathrm{kg}$ ) of both treated (AWB) and untreated (AWOB) extracts significantly decreased LDL and total cholesterol but decreased in the atherogenic index were only seen in treated (AWB) extract at both $200 \mathrm{mg} / \mathrm{kg}$ and $400 \mathrm{mg} / \mathrm{kg}$ respectively when compared with disease control group. However, there were no significant decreased serum VLDL and TG and increased HDL levels (Figure 2).

\subsection{Effect of okra extracts on Body weight and relative liver and heart weight}

After four weeks of the experiment, the body weights were measured. Significant $(\mathrm{P} \leq 0.05)$ decreased in body weight were seen in disease control and DC+200mg $/ \mathrm{kg}$ (AWOB) at about $25 \%$ when compared with normal control and other experimental groups. However, significant increased liver relative weight was recorded in disease control group when compared with other experimental groups. The liver relative weight was almost times ten of heart relative weight in all the experimental groups (Figure 3).

\subsection{Effect of okra extracts on carbohydrate metabolizing enzymes}

Figure 4 showed the change in the activities of hexokinase, glucose-6-phosphate dehydrogenase, fructose-1, 6- bisphosphatase, glucose-6-phosphatase in the liver of normal and experimental rats. The activities of hepatic gluconeogenic enzymes (fructose-1, 6 - bisphosphatase and glucose-6-phosphatase) were significantly $((\mathrm{P} \leq 0.05)$ increased in disease control group as compared to normal control group, whereas glycolytic enzyme (hexokinase), and pentose phosphate pathway enzyme (glucose-6-phosphate dehydrogenase) were significantly $((\mathrm{P} \leq 0.05)$ decreased in disease control group when compared to normal control group. However, administration of ethanol extract of okra and glibenclamide to disease rats reversed the changes in the activities of these hepatic enzymes in groups treated with $200 \mathrm{mg} / \mathrm{kg}$ and $400 \mathrm{mg} / \mathrm{kg}$ (AWB) and $30 \mathrm{mg} / \mathrm{kg}$ atorvastatin respectively as compared to disease control group.

\subsection{Effect of okra extracts on Malondialdehyde level}

Figure 5 showed the level of lipid peroxidation in the experimaental rats. Malondialdehyde level was significantly $(\mathrm{P} \leq 0.05)$ increased in disease control group as compared to normal control group. But the administration of ethanol extract okra significantly $((\mathrm{P} \leq 0.05)$ decreased the level of malondialdehyde as compared to disease control group with the exception of the group treated with $200 \mathrm{mg} / \mathrm{kg}$ (AWOB).

\subsection{Effect of okra extracts on liver HMG- CoA reductase activity}

Figure 6 showed the effect of the okra extracts on Liver HMG/Mevalonate Ratio. Significant $(\mathrm{P} \leq 0.05)$ increased in HMG/Mevalonate ratio were observed in groups treated with $400 \mathrm{mg} / \mathrm{kg}$ (AWB) and $30 \mathrm{mg} / \mathrm{kg}$ atorvastatin, which in turn significantly $(\mathrm{P} \leq 0.05)$ decreased the HMG-CoA reductase activity when compared with the disease control group.

\subsection{Effect of okra extracts on antioxidant enzymes in the experimental rats}

Figure 7 showed the activities of CAT, SOD, and GPx in normal and disease rats. There was a significant $(p \leq 0.05)$ reduction in the activities of CAT, SOD, and GPx in disease control rats. After administration with okra extracts the antioxidant activities in the groups treated with $400 \mathrm{mg} / \mathrm{kg}$ (AWB) and $30 \mathrm{mg} / \mathrm{kg}$ atorvastatin were well compared with normal control group. 


\subsection{Effect of okra extracts on non-enzyme antioxidant enzymes in the experimental rats}

Figure 8 showed the level of vitamin $C$ and vitamin $E$ in normal and disease rats. Significant $(p \leq 0.05)$ reduction in the level of non-enzymatic antioxidants was observed in the liver of disease control group rats as compared to normal control rats. Treatment with okra extracts (especially 200mg/kg and 400mg/kg (AWB) and $30 \mathrm{mg} / \mathrm{kg}$ atorvastatin to disease rats restored these enzymes activities when compared to disease control group.

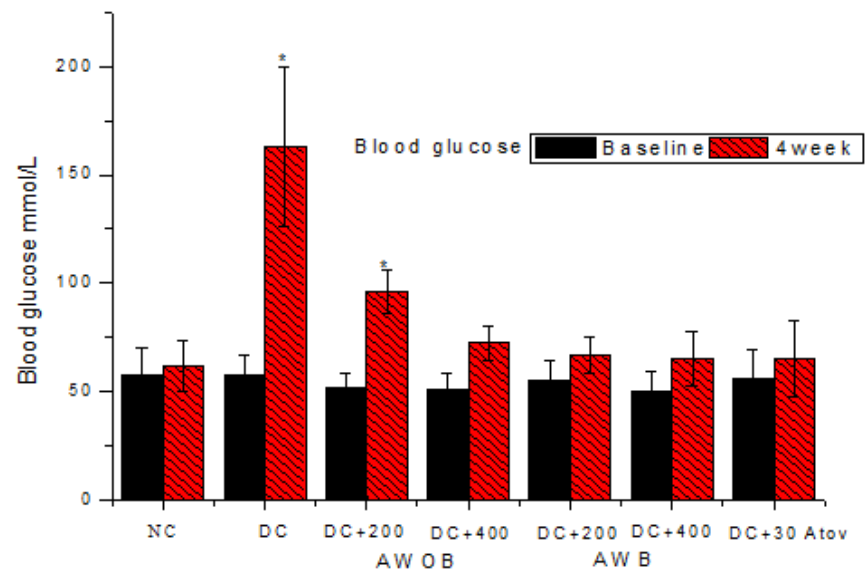

Figure 1: Effect of okra extracts on serum glucose level of experimental rats Values are expressed as means \pm SEM $(n=5)$. *Significant difference when compared with normal control (NC) $\mathrm{P} \leq 0.05$

Where $\quad \mathrm{NC}=$ Normal control, $\mathrm{DC}=$ Disease control, $\mathrm{DC}+200=$ Disease control $+200 \mathrm{mg} / \mathrm{kg}$ of the okra extract, $\mathrm{DC}+400=$ Disease control $+400 \mathrm{mg} / \mathrm{kg}$ of the okra extract, $\mathrm{DC}+30$ Atov. $=$ Disease control + $30 \mathrm{mg} / \mathrm{kg}$ of atorvastatin, $\mathrm{AWOB}=$ Okra without bioregulator, $\mathrm{AWB}=$ Okra with bioregulator.
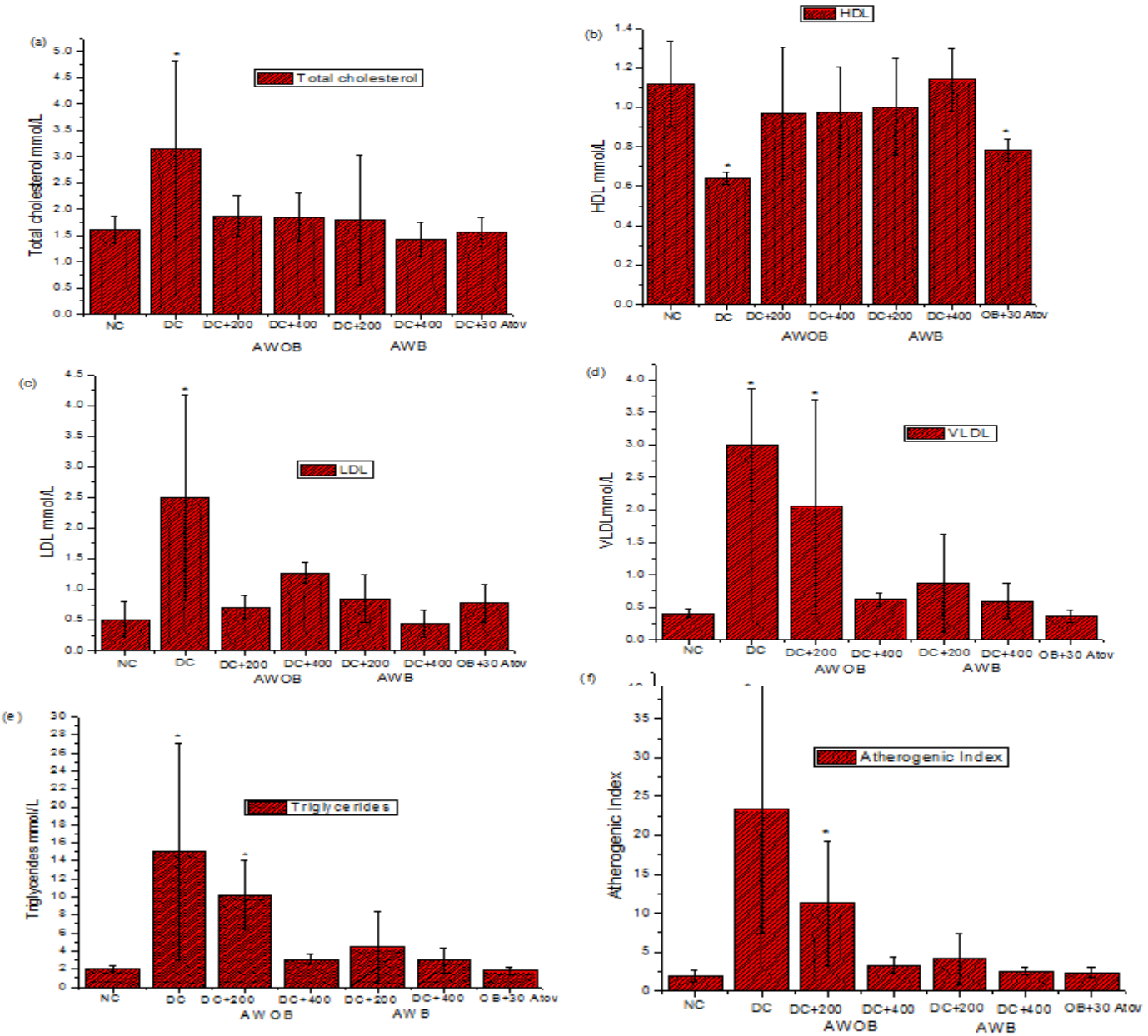

Figure 2: Effect of okra extract on serum lipid profiles of experimental rats 
Values are expressed as means \pm SEM $(n=5)$. *Significant difference when compared with normal control (NC) and other groups at $\mathrm{P} \leq 0.05$.
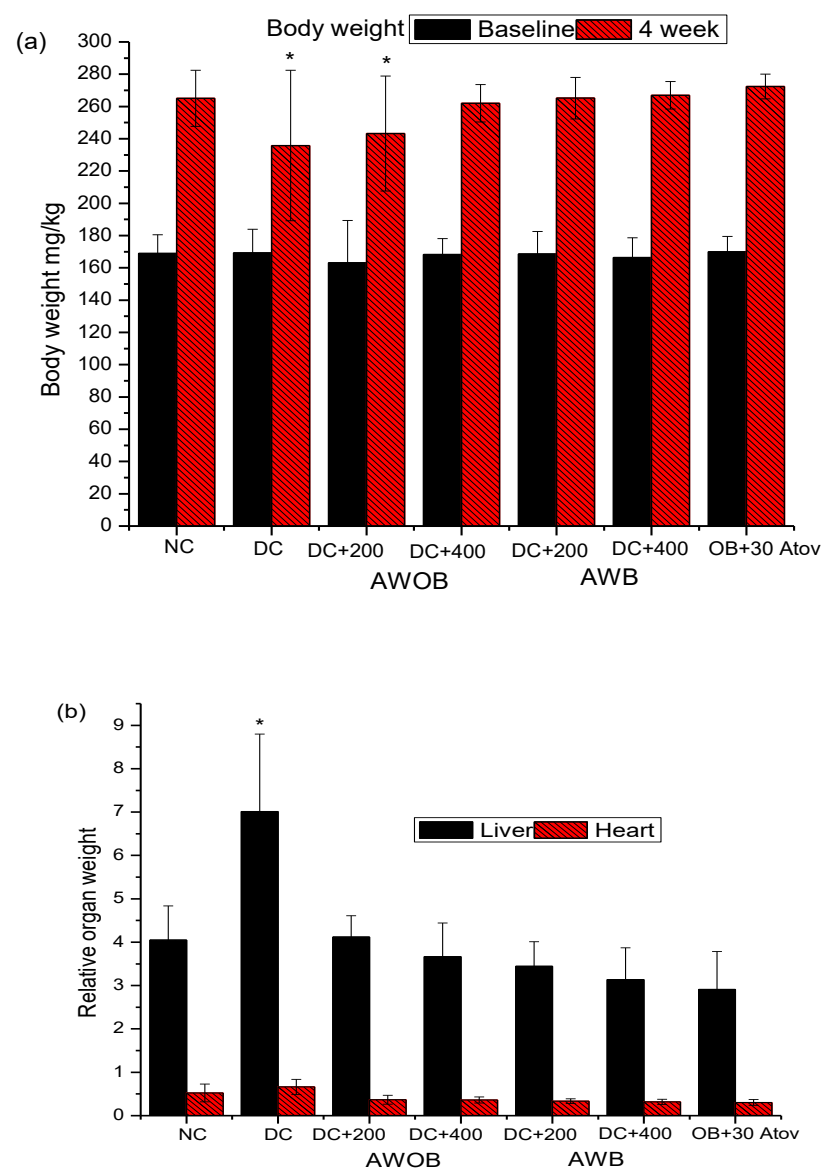

Figure 3: Effect of okra extracts on body weight, relative liver and heart weight of experimental rats Values are expressed as means \pm SEM $(n=5)$. *Significant difference when compared with normal control (NC) and other groups at $\mathrm{P} \leq 0.05$

Where $\quad \mathrm{NC}=$ Normal control, $\mathrm{DC}=$ Disease control, $\mathrm{DC}+200=$ Disease control $+200 \mathrm{mg} / \mathrm{kg}$ of the okra extract, $\mathrm{DC}+400=$ Disease control $+400 \mathrm{mg} / \mathrm{kg}$ of the okra extract, $\mathrm{DC}+30$ Atov. $=$ Disease control + $30 \mathrm{mg} / \mathrm{kg}$ of atorvastatin, $\mathrm{AWOB}=$ Okra without bioregulator, AWB $=$ Okra with bioregulator.
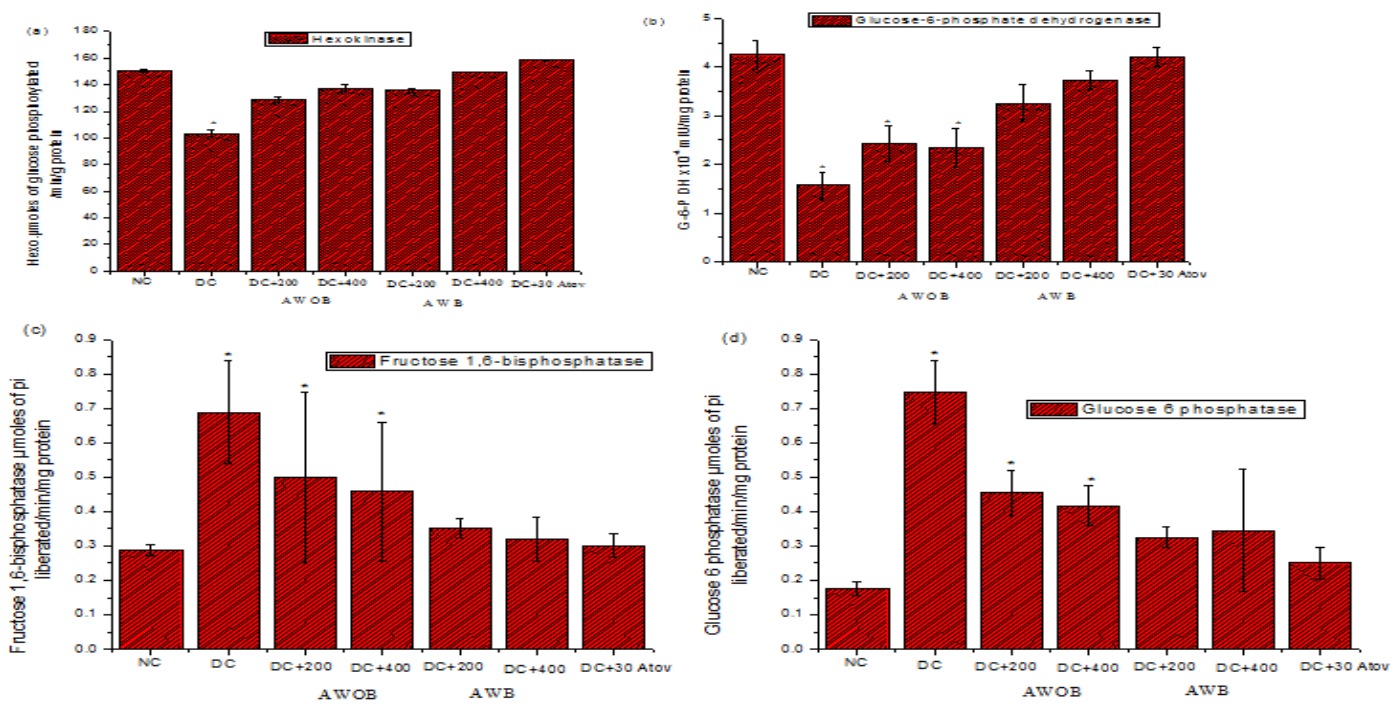

Figure 4: Effect of okra extracts on carbohydrate metabolizing enzymes in normal and diabetic rats 
Values are expressed as means \pm SEM $(n=5) . *$ Significant difference at $(\mathrm{P} \leq 0.05)$ when compared with normal control (NC)

Where $\quad \mathrm{NC}=$ Normal control, $\mathrm{DC}=$ Disease control, DC $+200=$ Disease control $+200 \mathrm{mg} / \mathrm{kg}$ of the okra extract, $\mathrm{DC}+400=$ Disease control $+400 \mathrm{mg} / \mathrm{kg}$ of the okra extract, $\mathrm{DC}+30$ Atov. $=$ Disease control + $30 \mathrm{mg} / \mathrm{kg}$ of atorvastatin, $\mathrm{AWOB}=\mathrm{Okra}$ without bioregulator, $\mathrm{AWB}=$ Okra with bioregulator.

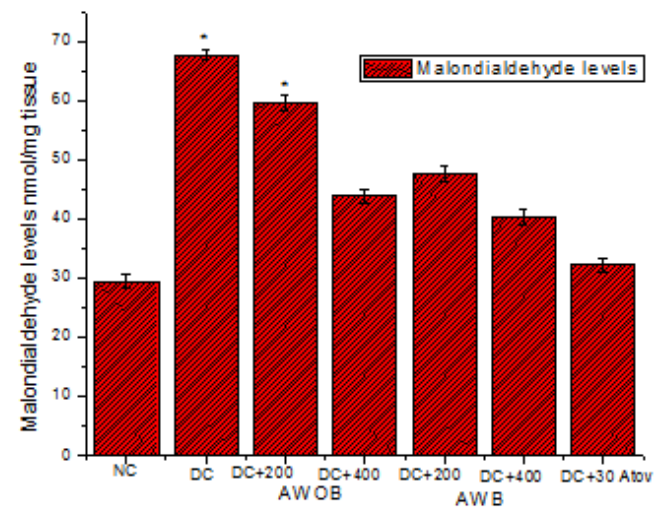

Figure 5: Effect of okra extracts on malondialdehyde level in experimental rats

Values are expressed as means \pm SEM $(n=5)$. *Significant difference when compared with normal control NC and other groups at $\mathrm{P} \leq 0.05$

Where $\quad \mathrm{NC}=$ Normal control, $\mathrm{DC}=$ Disease control, DC $+200=$ Disease control $+200 \mathrm{mg} / \mathrm{kg}$ of the okra extract, $\mathrm{DC}+400=$ Disease control $+400 \mathrm{mg} / \mathrm{kg}$ of the okra extract, $\mathrm{DC}+30$ Atov. $=$ Disease control + $30 \mathrm{mg} / \mathrm{kg}$ of atorvastatin, $\mathrm{AWOB}=$ Okra without bioregulator, $\mathrm{AWB}=$ Okra with bioregulator.
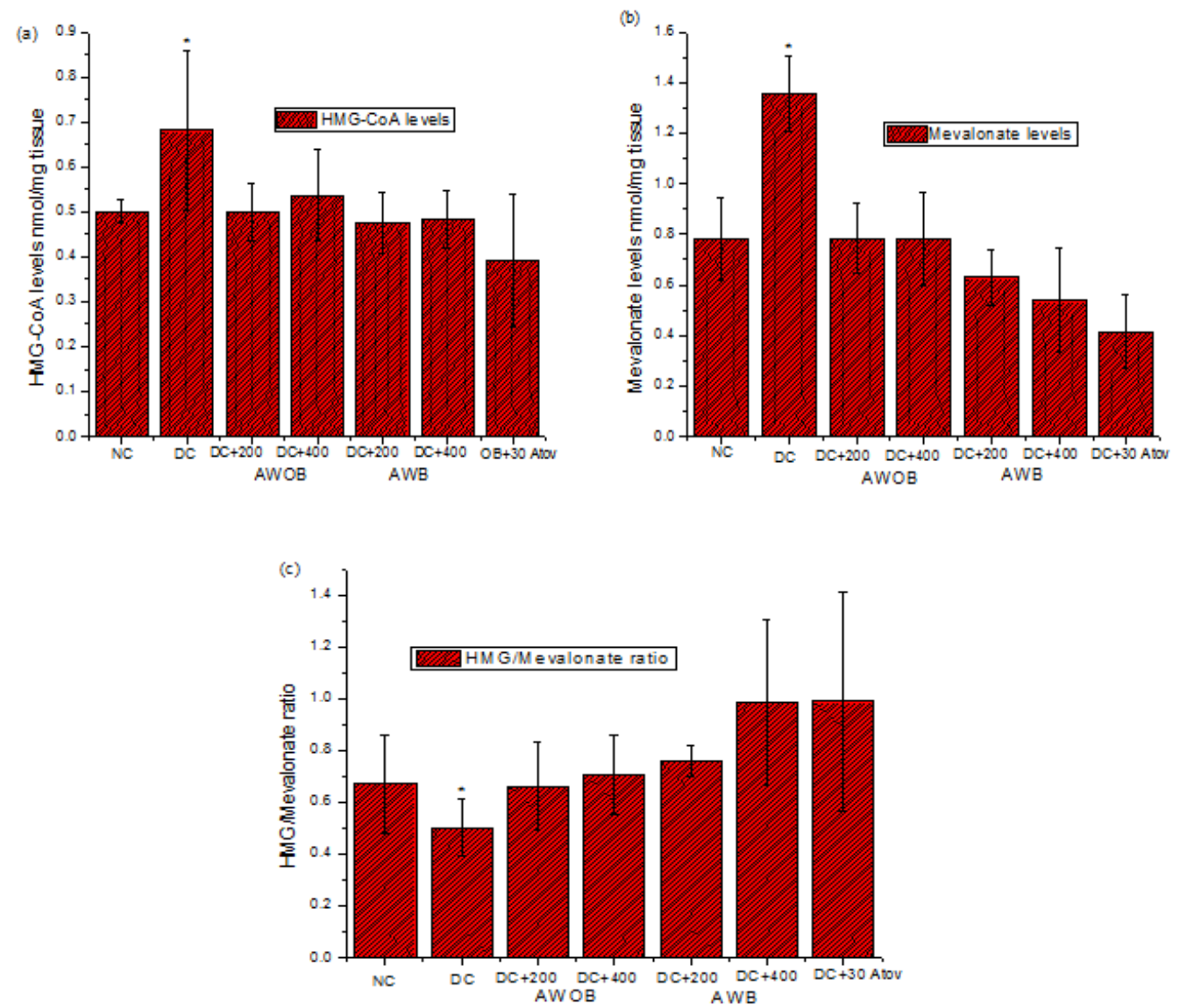

Figure 6: Effect okra extract on HMG-CoA activity in experimental rats 
Values are expressed as means \pm SEM $(n=5)$ *Significant difference when compared with normal control (NC) and other groups at $\mathrm{P} \leq 0.05$

Where $\quad \mathrm{NC}=$ Normal control, $\mathrm{DC}=$ Disease control, $\mathrm{DC}+200=$ Disease control $+200 \mathrm{mg} / \mathrm{kg}$ of the okra extract, $\mathrm{DC}+400=$ Disease control $+400 \mathrm{mg} / \mathrm{kg}$ of the okra extract, $\mathrm{DC}+30$ Atov. $=$ Disease control + $30 \mathrm{mg} / \mathrm{kg}$ of atorvastatin, $\mathrm{AWOB}=$ Okra without bioregulator, $\mathrm{AWB}=$ Okra with bioregulator.
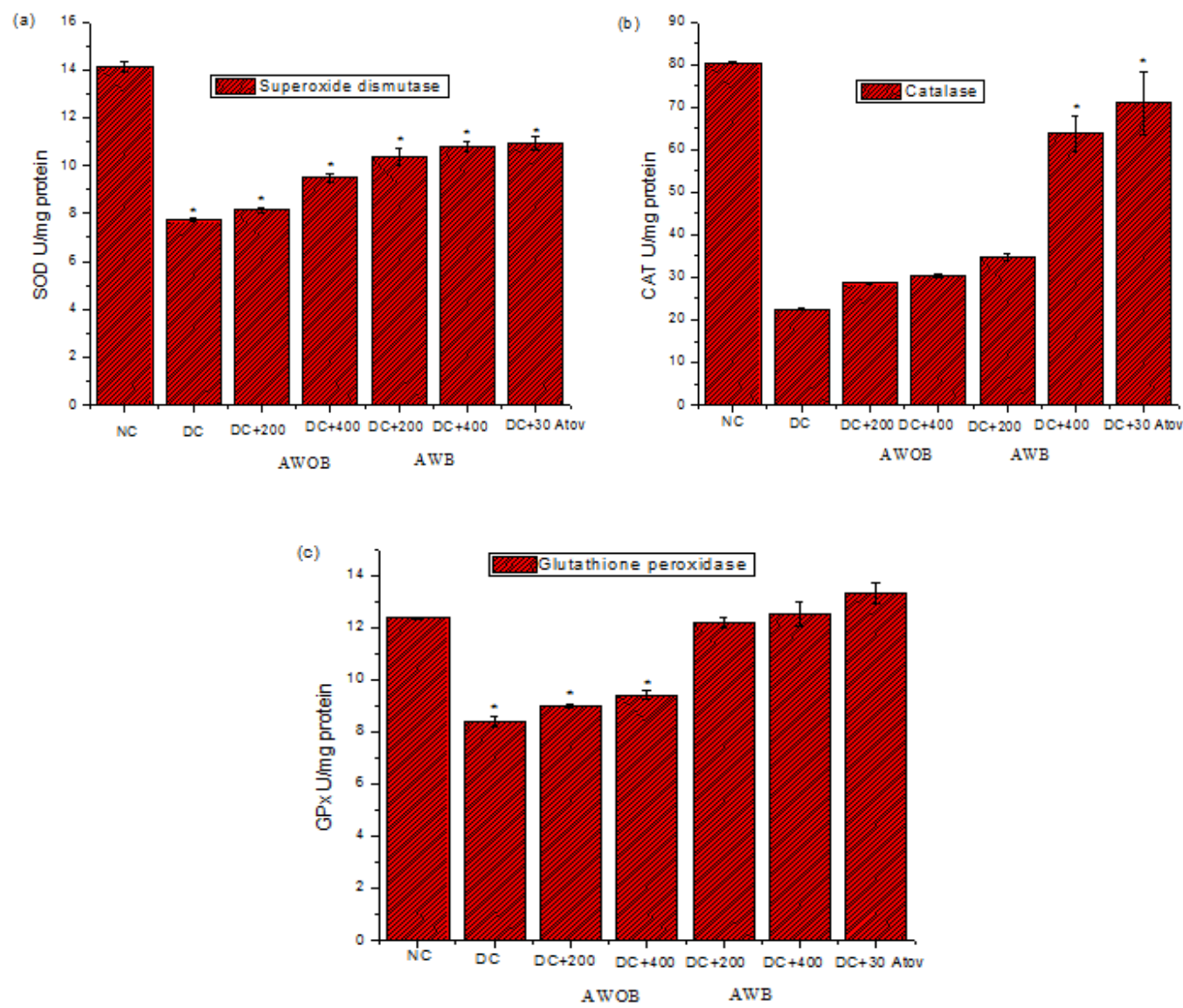

Figure 7: Effect of okra extracts on antioxidant enzymes in normal and diabetic rats

Values are expressed as means \pm SEM $(n=5)$. ${ }^{*}$ Significant difference at $(P \leq 0.05)$ when compared with normal control (NC)

Where $\quad \mathrm{NC}=$ Normal control, $\mathrm{DC}=$ Disease control, $\mathrm{DC}+200=$ Disease control $+200 \mathrm{mg} / \mathrm{kg}$ of the okra extract, $\mathrm{DC}+400=$ Disease control $+400 \mathrm{mg} / \mathrm{kg}$ of the okra extract, $\mathrm{DC}+30$ Atov. $=$ Disease control + $30 \mathrm{mg} / \mathrm{kg}$ of atorvastatin, $\mathrm{AWOB}=\mathrm{Okra}$ without bioregulator, $\mathrm{AWB}=$ Okra with bioregulator.

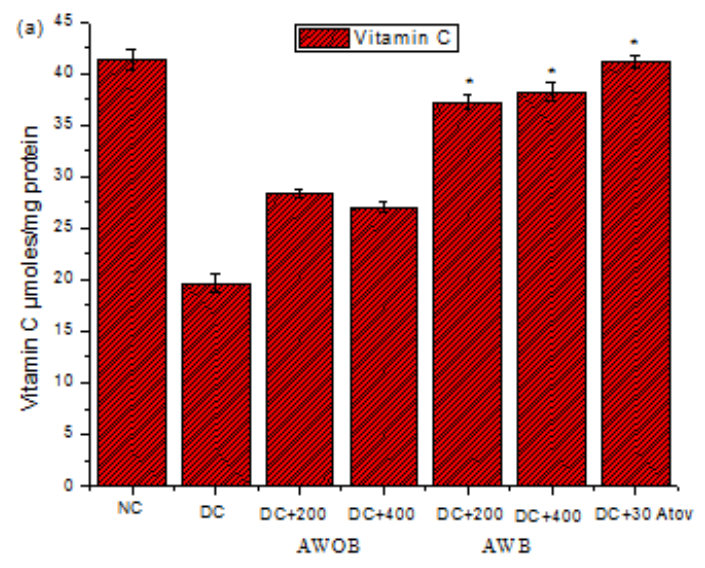




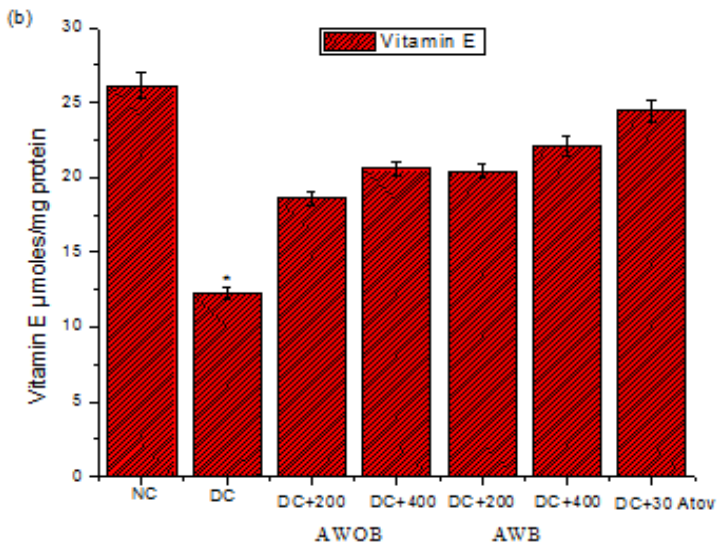

Figure 8: Effect of okra extracts on non-enzyme antioxidant enzymes in normal and disease rats Values are expressed as means \pm SEM $(n=5)$. * Significant difference at $(P \leq 0.05)$ when compared with normal control (NC) and other groups.

Where $\quad \mathrm{NC}=$ Normal control, $\mathrm{DC}=$ Disease control, $\mathrm{DC}+200=$ Disease control $+200 \mathrm{mg} / \mathrm{kg}$ of the okra extract, $\mathrm{DC}+400=$ Disease control $+400 \mathrm{mg} / \mathrm{kg}$ of the okra extract, $\mathrm{DC}+30$ Atov. $=$ Disease control + $30 \mathrm{mg} / \mathrm{kg}$ of atorvastatin, $\mathrm{AWOB}=$ Okra without bioregulator, $\mathrm{AWB}=$ Okra with bioregulator.

\section{Discussion}

Disturbances in lipid metabolism result to cardiovascular diseases. In spite of numerous class of hypolipidemic drugs used in the treatment, none of these existing ones are fully effective, totally safe and free from adverse effects. Hence, efforts are being made to find out safe and effective agents that may be beneficial in correcting the lipid metabolism and preventing cardiac diseases. This study was done to evaluate the hypolipidemic and glucose-lowering potential of extracts from bioregulator treated A. esculentus on tritoninduced hyperlipidemia rats. Effect of oral administration of ethanol extract of Abelmoschus esculentus fruits on experimentally induced hyperlipidemia was investigated. The okra extracts at a dose $400 \mathrm{mg} / \mathrm{kg}$ (AWB) showed significantly $(\mathrm{P} \leq 0.05)$ more blood glucose reduction than its $400 \mathrm{mg} / \mathrm{kg}$ (AWOB) dose. Also, treatment of both the doses of 200 and $400 \mathrm{mg} / \mathrm{kg}(\mathrm{AWB})$ significantly $(\mathrm{P} \leq 0.05)$ produced greater blood glucose reductions, which are comparable to $30 \mathrm{mg} / \mathrm{kg}$ atorvastatin when compared to 200 and $400 \mathrm{mg} / \mathrm{kg}$ (AWOB) doses. Extracts of okra exert their blood glucose lowering effect through inhibition of carbohydrate metabolizing enzymes. Reduction in blood glucose level by the extract may be the possible effect of polyphenols in the extract that regenerate damaged pancreatic islet $\beta$ cells, and hence, insulin secretion. This is similar to the findings of [27]. Triton X-100 has been widely used to block clearance of TGs-rich lipoproteins to induce acute hyperlipidemia in several animals [28]. The high levels of plasma cholesterol and TGs were due to Triton X-100 injection results mostly from an increase of VLDL secretion by the liver accompanied by a strong reduction of VLDL and LDL catabolism [29]. Ethanol extracts of okra at a dose of 200 and $400 \mathrm{mg} / \mathrm{kg}$ (AWB) significantly lowered the TGs and cholesterol levels. The reduction of TC by the A. esculentus extract was associated with a decrease of its LDL fraction, which is the target of several hypolipidemic drugs. This result suggests that cholesterol-lowering activity of the herb extract can be a result from the rapid catabolism of LDL-C through its hepatic receptors for final elimination in the form of bile acids. HDL aids the translocation of cholesterol from the peripheral tissue, such as arterial walls to the liver for catabolism, hence, reduction in plasma HDL is a risk factor for developing atherosclerosis. Increased levels of HDL (cardio protective lipid) may be due to the increase in the activity of lecithin cholesterol acyltransferase, which plays a key role in incorporating the free cholesterol into HDL and transferring back to VLDLs or intermediate density lipoproteins, which are taken back by the liver cells. The increased level of HDL-cholesterol and decreased cholesterol level along with its LDL fraction, which is evident from the results could be due to an increased cholesterol excretion and decreased cholesterol absorption through gastro intestinal tract. Several studies have shown that an increase in HDL-C is associated with a decrease in coronary risk [30-32]. A significant body weight loss was observed after the administration of triton-X may be due to the degradation of structural proteins. Treatment at doses of $400 \mathrm{mg} / \mathrm{kg}$ (AWOB), 200 and $400 \mathrm{mg} / \mathrm{kg}$ (AWB) showed significantly increased in body weight compared to disease control. This action may be due to the preventive effect of extracts on structural protein degradation. Triton $\mathrm{X}$ produced an increase in relative liver weight, without significantly affecting relative heart weight of animals. This result is in tandem with the observation of [30]. Increased in MDA level and decreased in antioxidant enzymes and non-enzyme antioxidant levels indicating enhancement of oxidative stress. These findings are in agreement with the observation of [33]. Decreased activity of HMG -CoA by the okra extracts showed that the extracts are potential HMG-CoA reductase inhibitor. 


\title{
VI. Conclusion
}

In conclusion, the antihyperlipidemic and anti- glycemic activities of okra extracts at 200 and 400 $\mathrm{mg} / \mathrm{kg}$ (AWB) against Triton $\mathrm{X}-100$ shows a significant $(\mathrm{P} \leq 0.05)$ decrease in blood glucose, TC, TG, LDL-C, VLDL, AI, MDA, HMG-CoA reductase activity, gluconeogenic enzymes and significant $(\mathrm{P} \leq 0.05)$ increase in HDL-C, glycogenic enzymes, antioxidant enzymes and non-enzymes antioxidant in a dose- dependent manner comparing with standard atorvastatin- treated group. However, further studies are still going on to evaluate the actual active constituents responsible for the activity and mechanisms of these effects.

\section{Acknowledgements}

Authors are grateful to the director of INSA JRD TATA Dr. Amudeswari of CICS and JSS College of Pharmacy, Ooty, Tamil Nadu, India for their constant support throughout this research work.

\section{Funding}

We are grateful for INSA-JRD TATA FELLOWSHIP of India for financing this project.

\begin{abstract}
Abbreviations
$\mathrm{AWB}=$ Abelmoschus esculentus with bioregulator, $\mathrm{AWOB}=$ Abelmoschus esculentus without bioregulator, $\mathrm{ATOV}=$ Atorvastatin, $\mathrm{CAD}=$ Coronary artery diseases, $\mathrm{CMC}=$ Carboxymethyl cellulose, HDL-C $=$ High density lipoproteins cholesterol, $\mathrm{HL}=$ Hyperlipidemic control group, LDL-C $=$ low density lipoproteins cholesterol, , P.o. $=$ Per oral, $\mathrm{S} . \mathrm{D}=$ Standard deviation, $\mathrm{MDA}=$ Malondialdehyde, $\mathrm{TC}=$ Serum total cholesterol, $\mathrm{TG}=$ Triglycerides, $\mathrm{VLDL}-\mathrm{C}=$ Very low density lipoproteins cholesterol, $\mathrm{CAT}=$ Catalase, $\mathrm{SOD}=$ Superoxide dismutase, $\mathrm{GPx}=$ Glutathione peroxidase, $\mathrm{HMG}$ - $\mathrm{CoA}=3$-hydroxy-3-methylglutaryl, $\mathrm{AI}=$ Atherogenic index .
\end{abstract}

\section{References}

[1] G.D. Kolovou, K. K. Anagnostopoulou,D. V. Cokkinos,"Pathophysiology of dyslipidaemia in themetabolic syndrome,"Postgraduate Medical Journal 81 (956), 2005, 358-366.

[2] R.M. Krauss, Y.A. Kesaniemi, "Cardiovascular disease and hyperlipidaemia," Current Opinion in Lipidology, 5 (4), 1994, 249-251.

[3] G.S. Hotamisligil, E. Erbay, Nutrient sensing and inflammation in metabolic diseases. Nat Rev Immunol. 8, 2009, 923-34

[4] J.H. Goedecke, J.A. Dave, M.V. Faulenbach, Insulin response in relation to insulin sensitivity: an appropriatebeta-cell response in black South African women. Diabetes Care. 32(5), 2009, 860-65

[5] D. Hayoz, T. Ziegler, Diabetes mellitus and vascular lesions. Metabolism. Curr. Ther. Res., 47,1998, 16-19

[6] D. Bonnefont, J.P. Bastard M.C. Jaudon, J. Dellatre, Consequences of diabetes status on the oxidant/antioxidant balance. Diabetes Metabol. 26, 2000, 163-76

[7] N. J. Stone, "Lipidmanagement: current diet and drug treatment options," The American Journal of Medicine, 101(4), 1996, supplement $1,40 \mathrm{~S}-49 \mathrm{~S}$,

[8] Y. S. Lin, S. Mousa, N. Elshourbagy, S. A. Mousa, "Current status and future directions in lipid management: emphasizing lowdensity lipoproteins, high-density lipoproteins, and triglycerides as targets for therapy," Vascular Health and Risk Management, 6 (1),2010,73-85.

[9] M. Kobayashi, T. Kagawa, K. Narumi, S. Itagaki, T. Hirano, K. Iseki, "Bicarbonate supplementation as a preventive way in statinsinduced muscle damage," Journal of Pharmacy and Pharmaceutical Sciences, 11(1), 2008,1-8.

[10] J. R Guyton, H. E. Bays, "Safety considerations with niacin therapy,"The American Journal of Cardiology, 99 (6), 2007, S22-S31.

[11] W. C. Lakey, N. Greyshock, J.R.Guyton, "Adverse reactions of Achilles tendon xanthomas in three hypercholesterolemic patients after treatment intensification with niacin and bile acid sequestrants," Journal of Clinical Lipidology, 7 (2), $2013,178-181$.

[12] C.C. Allain, L.S. Poon, C.S.G. Chan, W. Richmondn, P.C. Fu, Clin. Chem. 20, 1974, 470

[13] W.T. Friedewald, R.I. Levy, D.S. Fredrickson, Estimation of the concentration of low-density lipoprotein cholesterol in plasma, without the use of the preparative ultracentrifuge ClinChem. 18, 1972, 499-502. [PubMed]

[14] N. Taleb-Dida, D. Krouf, M Bouchenak, "Globularia alypum aqueous extract decreases hypertriglyceridemia and ameliorates oxidative status of the muscle, kidney, and heart in rats fed a high-fructose diet," Nutrition Research. 31(6), 2011, 488-495

[15] N. Brandstrup, J.E. Kirk, C. Bruni, Determination of hexokinase in tissues. J Gerontol 12, 1957,166-71.

[16] H.A. Ellis, H.N. Kirkman, A colorimetric method for assay of erythrocyte glucose-6-phosphate dehydrogenase. Proc Soc Exp Biol Med. 106, 1961, 607-609.

[17] H. Koide, T. Oda, Pathological occurrence of glucose-6-phosphatase in liver disease. Clin Chim Acta. 4, 1959, 554-561

[18] C.H. Fiske, Y. Subbarow The colorimetric determination of phosphorus J BiolChem, 66, 1925, 375-400

[19] J.M. Gancedo, C. Gancedo, Fructose-1, 6-Bisphosphatase, phospho fructokinase and glucose-6-phosphate dehydrogenase from fermenting and non-fermenting yeasts. Arch Microbiol 76, 1971, 132-138.

[20] H. Ohkawa, N. Ohishi, K. Yagi, "Assay for lipid peroxides in animal tissues by the thiobarbituric acid reaction," Analytical Biochemistry. 1979; vol. 95, no. 2, pp. 351-358

[21] Venugopala Rao A and Ramakrishnan S. "Indirect assessment of hydroxymethyl glutarylCoA reductase (NADPH) activity in the liver tissue," Clinical Chemistry 21(10) 1975, 1523- 1525.

[22] K.A. Sinha, Colorimetric assay of catalase. Anal. Biochem., 47, 1972, 389-394.

[23] D. Kakkar, B. Das, P.N. Viswanathan, A modified spectro-photometric assay of superoxide dismutase.Ind.J.Biochem. Biophys., 21, 1984, 130-132.

[24] ] J.T. Rotruck, A.L. Pope, H.E. Ganther, A.B. Swanson, D.G. Hafeman, W.G. Hoekstra, Selenium:Biochemicalroles as a component of glutathione peroxidase. Science., 179, 1984, 588-590.

[25] J.H. Roe, C.A. Kuether, The determination of ascorbic acid in whole blood and urine through the 2,4-dinitrophenylhydrazine derivative of dehydroascorbic acid. J. Biol. Chem. 147, 1943, 399

[26] R. T. M. Baker, S. J. Davies, Changes in tissue $\alpha$-tocopherol status and degree of lipid peroxidation with varying $\alpha$-tocopheryl acetate inclusion in diets for the African catfish. Aquacult. Nutr. 2, 1996, 71-79. 
[27] N. Møller, K.S. Nair, Diabetes and protein metabolism. Diabetes. 57, 2008,3-4. [PubMed]

[28] A. Kellner, J.W. correll, AT. Ladd, Sustained hyperlipemia induced in rabbits by means of intravenously injected surface-active agents. J Exp Med. 93,1951,373-384. [PMC free article] [PubMed]

[29] S. Otway, D.S. Robinson, The effect of a non-ionic detergent (Triton WR 1339) on the removal of triglyceride fatty acids from the blood of the rat J Physiol. 190, 1967, 309-319. [PMC free article] [PubMed]

[30] N. Taleb-Dida, D. Krouf, M. Bouchenak, "Globularia alypum aqueous extract decreases hypertriglyceridemia and ameliorates oxidative status of the muscle, kidney, and heart in rats fed a high-fructose diet," Nutrition Research, 31(6), 2011, 488-495.

[31] A. R Borate, A. A. Suralkar, S. S. Birje, P. V. Malusare, and P. A. Bangale, "Antihyperlipidemic effect of protocatechuic acid in fructose induced hyperlipidemia in rats," International Journal of Pharma and Bio Sciences, 2 (4), 2011, 456-460.

[32] G. L. Kelley, G. Allan, S. Azhar, "High dietary fructose induces a hepatic stress response resulting in cholesterol and lipid dysregulation," Endocrinology, 145(2), 2004, 548-555.

[33] S. Reddy, S. P. Ramatholisamma, R. Karuna, D. Saralakumari, "Preventive effect of Tinospora cordifolia against high fructose dietinduced insulin resistance and oxidative stress in male Wistar rats," Food and Chemical Toxicology, 47(9), 2009, 2224-2229.

IOSR Journal of Pharmacy and Biological Sciences (IOSR-JPBS) is UGC approved Journal with Sl. No. 5012, Journal no. 49063.

A.M. Esan. "Antihyperlipidemic And Glucose Lowering Effect Of Extract Of Bioregulator Treated Okra (Abelmoschus Esculentus L.) Fruits in Triton-Induced Hyperlipidemia Rats." IOSR Journal of Pharmacy and Biological Sciences (IOSR-JPBS) 12.4 (2017): 39-50. 